\title{
Good Times, Brought to you by Brand Modi
}

Kaur, Ravinder

Published in:

Television \& New Media

DOI:

10.1177/1527476415575492

Publication date:

2015

Document version

Early version, also known as pre-print

Citation for published version (APA):

Kaur, R. (2015). Good Times, Brought to you by Brand Modi. Television \& New Media, 16(4), 323-330.

https://doi.org/10.1177/1527476415575492 


\section{Good Times, Brought to You by Brand Modi}

Television \& New Media sagepub.com/journalsPermissions.nav DOI: $10.1177 / 1527476415575492$ tvn.sagepub.com

@SAGE

\title{
Ravinder Kaur ${ }^{1}$
}

\begin{abstract}
The impending arrival of the long awaited "good times" emerged as a powerful meme in the 2014 general elections in India. The vague but exhilarating promise of good times was not only translated into catchy campaign slogans but also acquired its own fast-circulating hashtags, domain names, and strong everyday presence on social media. In this article, I open up the notion of good times through an account of \#acchedin and locate it within the longer trajectory of neoliberal economic reforms. I ask what good times might even mean in a nation that has transformed itself fully into commodity-form to become an attractive investment destination for global investors. The newly crafted Brand Modi, the natural inheritor and prime agent of 1990s Brand India, now works in tandem in anticipation of the long awaited, and ever elusive, transformative epochal threshold of good times ahead.
\end{abstract}

\section{Keywords}

brand India, brand Modi, good times, economic reforms, capitalism, India

On May 16, 2014,@narendramodi sent a fifty-nine character long tweet that was to become the most "retweeted tweet" in India. "India has won, Bharat ki vijay, acche din aane wale hai" ("India has won, good times are about to arrive") succinctly announced Narendra Modi's victory in the sixteenth general elections. In less than a few hours, the message had already been retweeted more than thirty-seven thousand times, and \#achhedin ("Good Days" or "Good Times") became one of the prime trending hashtags in that period. Since its peak in the month of May, the \#achhedin has acquired an enduring presence in media_-from Twitter, Facebook, Instagram, Youtube, and blogs to more conventional newspapers and magazines. If on eventful days, the \#achhedin

\section{'University of Copenhagen, Denmark}

\section{Corresponding Author:}

Ravinder Kaur, Faculty of Humanities, Department of Cross-Cultural and Regional Studies, University of Copenhagen, Building 10, Karen Blixens Vej 4, Copenhagen 2300, Denmark.

E-mail: rkaur@hum.ku.dk 
hashtag frames thousands of tweets and posts, on dull days, it continues to record its presence a few hundred times. Its ubiquitous presence indeed goes far beyond the quantifiable analytics of the new social media. In fact, the very idea of "good times" has become a part of the popular political vocabulary in India. It has also emerged as the much-publicized contentious field upon which the interplay of collective desires, aspirations, and perceived obstacles to those takes place.

The entry of this catchy slogan in the electoral battle has somehow brought to surface dramatic transformations, ruptures, or what pundits like to call the changing "mood of the nation" that continues to reconfigure postreform India. The notion of good times, here, at once vague and full of promise and hope, I suggest is now shorthand for an altogether new consensus; I will call it the "postreform consensus" that is gathering force after a quarter century of structural adjustments in India. If the old so-called "Nehruvian consensus" was deeply embedded in the postcolonial nation's genetic design and signaled a secular socialist state (Guha 2007; Khilnani 1997; Roy 2007), then the new rhetoric of good times signaled a decisive rightward shift to a capitalist dreamworld dressed up in a Hindu cultural nationalism that the aspiring middle class roots for (Kaur, forthcoming). Or put differently, the idea of good times we encountered in the 2014 elections, I will argue, discloses the historical moment when capitalism was reified as the sole vehicle of people's aspirations - that is, unchallenged by any other political alternative. What I want to unpack here is not only the contentious field upon which the consensus around good times has emerged but also the making of Brand Modi as the prime agency that promises to bring good times to the people.

To be sure, the idea of good times is not novel, for it has appeared in modern Indian politics in various garbs before, as a recurrent event, forever seeking advancement on the path toward the future. In this frame, the project of good times, new times, or broadly speaking, novelty as such has always been the unfinished business of modernity, an invitation to reinvent itself (Koselleck 2004; North 2013). If the trope of naya zamana or naya daur ("new times" or "new era") defined the epoch-changing, hopeful years of post-Independence India, then the trope of "India Shining" appeared as its forceful incarnation in the early 2000s. The promise of \#acchedin can be traced within this broad genealogy of novelty in India even as it signals a major shift therein.

\section{The Post-reform Consensus}

At the heart of this popular hashtag lies a yet unfolding story of the corporatization of the Indian nation-state (Comaroff and Comaroff 2009). By corporatization, I suggest not only the nation's transformation into a business-like operation aimed at creating surplus wealth through disinvestment and privatization but also the bid to turn it into an "attractive investment destination" for global investors. This transformed self, popularly called "India Inc.," over the past two decades was given a corporate identityBrand India - that publicizes the speculative economic value of the nation in its commodified form (Kaur 2012). This process of corporatization of the nation has been far from smooth since the program of liberalization, privatization, and globalization, 
or LPG, as the popular acronym went, was introduced in the summer of 1991 (Bardhan 2010; Jalan 1996).

The eventful decade of the 1990s is particularly characterized by ideological battles waged over liberalization both by Left parties and various right-wing groups in India albeit for different reasons. Right-wing groups like the Swadeshi Jagran Manch (Forum for the Awakening of Swadeshi), an offshoot of the Hindu nationalist organization Rashtriya Swayamsevak Sangh (National Volunteer Organization or RSS), shared the Left's opposition to the market economy even if the former's argumentation was based on distinct arguments about indigeneity and self-reliance or swadeshi. While the ideological opposition of the Left was not much of a surprise, more significant was how the Hindu right's swadeshi argument ${ }^{1}$ became the locus for countering the liberalization program in its first decade (see Mazzarella 2003). An equally important development in the second decade of liberalization was how, in a complete volte-face, RSS made economic reforms a part of its political agenda. This turn-around in the economic policy of RSS, the parent organization of the ruling Bharatiya Janata Party (BJP), sought to align the party with the global trend of right-wing neoliberal discourse, on one hand, and to counter the strong pro-reform credentials of the Congress Party, on the other. The fact that the Congress Party had facilitated the "opening up" of the Indian economy in 1991 meant that it was considered the "natural party of reforms" in the popular sphere. If this policy rearrangement helped the RSS/BJP to counter the political appeal of the Congress Party among the reform-minded middle class, it also augured a more or less consensual space where the opposition to the reforms assumed a token form. Yet the making of this political consensus has not only been contentious but has also underpinned a series of dramatic rearrangements.

Consider the ironic twist that could hardly have been imagined in the 1990s- the Congress Party, the original party of economic reforms, is now deemed to be less committed to its own liberalizing economic agenda when compared with the BJP. This change in perception is often blamed upon the last decade of Congress policy of "reforms with a human face" that allowed concessions like the Food Security Bill and "right-to-work" schemes providing subsidized food and guaranteed days of work respectively to the poorest. In this shifting map of liberalization, the BJP has now assumed the mantle of the most reform-minded party. If the Congress Party and the BJP continue to raise the political stakes and push for ever-more reforms, the socialist and communist parties in contrast have toned down their oppositional pitch in the past decade. States like West Bengal, Uttar Pradesh, and Bihar, ruled broadly by socialist or avowedly "pro-people" parties, have also sought to reinvent their image as business-friendly destinations within India in a bid to compete with Gujarat, Tamil Nadu, and Andhra Pradesh that are seen as hubs of innovation and investment. The larger debate has clearly moved from challenging the structures of capitalism that were already gaining ground in the 1990s to asking for fairer distribution of wealth in recent years (see, for example, Sen and Dreze 2013). The very project of capitalism is no longer openly questioned within mediated public debate (see Chakravartty and Sarkar 2013). 
Once we begin unpacking this genealogy, it becomes apparent how the promise of good times speaks to, or perhaps represents in a condensed form, this particular historical moment. While \#acchedin can be traced within this discourse of novelty and change, it nevertheless differs from its previous forms in two ways. First, even when on surface it seems vague in its formulation, it is actually associated with specific goals or processes that are deemed as guarantors of good life and long "held-back" aspirations of the common man. And second, capitalism is now a priori taken to be the vehicle that will deliver those aspirations/dreams to the common man.

Consider a sample of tweets that were tagged with \#acchedin in August-September 2014:

- @theshankhnaad tweeted, "Indian economy grew at its fastest rate during the past quarter" to mark the comeback of desirable growth rate at $5.7 \%$ \#acchedin;

- @devanghvyas "inflation falls to 5 year low! \#acchedin";

- @siddharthpaim “(Reserve Bank of India Governor) Rajan feels macroeconomic indicators are improving \#acchedin started";

- @eternit96426605 “April-June FDI inflow increased by 33\%, finalized northeast industrial corridor with Japanese \#acchedin";

- @yessalamsaffron wrote "Tata Motors to enhance city transportation across India by providing 2700 new buses \#acchedin";

- @tajinderbagga anticipated that "electricity prices in Delhi will be reduced again from Sept 11 \#acchedin"; and

- @goyalsanjeev rejoiced that "Aussie PM making personal delivery, India gets back 2 stolen ancient priceless idols \#acchedin.”

These tweets reveal three main themes.

First, the initial four tweets relate to the surge in the economy, which had been sluggish since the summer of 2013. The markers of optimism include rising growth rates, a fall in inflation, an increase in foreign direct investment flows, and a positive assessment by the governor of the Reserve Bank of India. Interestingly, the graph showing the rising growth curve in the newspaper article accompanying the first tweet was described as "acche din are here." That the logic of economic growth is at the core of good times was reiterated in a recent article in which the author anticipates major economic gains from acche din, beginning with surge in foreign direct investment flows, high economic growth rates, and most of all, recognition from the global investors and managers of capital (Mukherjee 2014). The second broad theme that emerges in the subsequent tweets is the availability of high-tech infrastructure and good governance. The last theme relates to the restoration of lost treasure (and thereby respect) and the recognition of India's great civilizational culture by foreign nations. Broadly speaking, these three main themes tend to structure the \#acchedin in a distinct direction where capitalism appears to be the uncontested path to achieve the desired goals. What is obvious here is that even though critics of the BJP often describe the idea of good times as vague, empty, and feel-good, it turns out to be more concrete. It is fully 
aligned with the neoliberal ideals of higher growth rates, capital flows, and good governance, which in turn will ensure cultural recognition and restoration of national pride.

\section{Brand Modi's Promise}

The central figure in the \#acchedin story is that of Modi who during the election campaign successfully branded himself as the action-oriented leader, the only one capable of bringing the good times to the common man. As far as hashtags go, \#acchedin appears more often than not in conjunction with \#Namo or @ narendramodi, his official Twitter handle. The two are now entwined in public imagination to an extent that if the current project of "good times" is predicated upon Modi's abilities, then his strong leadership itself can only be affirmed by the project's success. In other words, the project of "good times" and the making of Brand Modi are now intricately tied together; the success of one is the success of the other, and vice versa.

The construction of Brand Modi as the prime agent of good times at this moment is in itself telling about the nature of the project. The first key development to consider here is the conversion of a longtime RSS pracharak (volunteer/propagator) into a firm believer in the neoliberal magic of the "economic growth" agenda. Since its inception in 1925, the RSS has described itself as a cultural organization that was concerned with the Hindu self-identity and voluntary service to the community (Basu et al. 1993; Jaffrelott 1996). The economic agenda had largely been absent in the organizational priorities until 1990s when its offshoot Swadeshi Jagran Manch became a strong critic of the reform program facilitated by the Congress Party. This feature began changing in Gujarat under Modi's regime, which presented growth and development as signatures of his leadership (Bobbio 2012; Sud 2012). His government was effectively publicized as an epoch-changing event even though the primacy of trade and commerce in this region has a history that long precedes his rule. The ports of Gujarat have historically been busy trading hubs, just as its population has almost always had a transnational character due to migration (Simpson 2006). The contemporary prosperity of Gujarat — which was presented in the 2014 elections as a report card of achievements of the "Gujarat model" of economic growth (see Chakravartty \& Roy and Mudgal, IN PRESS) — can be traced back to the policy initiatives undertaken by the postcolonial government. What made the Modi regime different was the adoption of the global language of neoliberalism-good governance, growth/investment, and development - that was well understood by policymakers, investors, and middle-class consumers at home and abroad.

This shift was enabled by first creating an internal consensus within the RSS that is still occasionally seen as the roadblock to full reforms (Bloomberg 2014). The logic that underpinned this change was the prospect of appealing to a broader electoral constituency of reform-minded public that did not necessarily adhere to the agenda of cultural conservatism. The current sarsanghchalak (the RSS chief) Mohan Bhagwat is said to have altered the status quo when he unambiguously stated to a group of industrialists soon after Modi's nomination that the RSS was "not opposed to liberalization, 
privatization and FDI . . times change and views should change with the times as well" (Kanwal 2013). This much-publicized change in stance addressed two concerns at once. First, it allayed middle-class anxiety about price inflation, diminishing employment opportunities, and general economic gloom. And second, it helped divert attention away from the public scrutiny over the 2002 Gujarat violence that Modi has never been fully able to distance himself from (Shani 2007). As growth/development became the core ingredients of carefully manufactured Brand Modi, it became easier for foreign governments and agencies that had thus far held back from Modi to move beyond the past violence.

Although Brand Modi has circumvented associations with communal violence by drawing the public attention to his self as the vikas purush (literally, "the development man"), the communal polarization in Gujarat nevertheless did strengthen his strongman image in the public eye. It is no coincidence that Modi used the rhetoric "56 inches large chest" repeatedly to establish himself as the desirable embodiment of masculinity, and more so in comparison to the then Prime Minister Manmohan Singh who is of slender physical build (see Srivastava, IN PRESS). Thus, Brand Modi is manufactured upon a well-calibrated play of attention and diversion, of excessive publicity that overshadows what the public ultimately knows not to know. Like all brands, Brand Modi seeks to mediate certain qualities and effects that promise to change the lives of its consumers. In this specific case, Brand Modi promises to bring alive the middle-class dreams of prosperity, opportunities, and a better standard of living, all delivered by a strong leader who does not flinch in the face of opposition.

\section{Dreamworlds of Capital}

If we take \#acchedin to be the sign of a new postreform consensus, then how are we to interpret what the social media analysts call the "negative usage" of this hashtag? What I want to bring into this discussion is the wider political spectrum within which \#acchedin exists on social media as well as the larger public discourse. As the euphoria of Modi's victory began subsiding, the public critique and dissent took shape precisely around the idea of "good times." At the crux of this critique was the nondelivery of good times that had been promised during the time of election campaign. For example, the long spells of electricity cuts in Delhi (called "load-shedding" during the excessively hot summer months) were dubbed as \#acchedin by an irate public. Similarly, the continuing inflation, the failure of bringing "black money" back from the foreign banks, especially once the Modi government had celebrated its hundred days, were tagged with \#acchedin. The ironic use of this hashtag was meant to empty out the original meanings it was imbued with, on one hand, and, on the other, to shame the regime into action. The critics often invoke \#acchedin together with a question mark to ask whether a given negative condition is what the promise of good times was all about. The Twitter analytics of the past five-month period show how the negative use of \#acchedin has outgrown the positive use further we come from the celebratory period of Modi's electoral victory. We might ask the following: What is this negative use symbolic of? What kind of disillusionment does this hint at? 
At a first glance, it might seem that the project of "good times" is what the public is disillusioned with, given the strong association of Modi with this endeavor. Yet once we begin picking the criticism apart, it becomes clear that the disillusionment is not with the project itself but with the brand that promised to deliver it. Recall here the postreform consensus that has positioned capitalism as the prime facilitator of good times, prosperity, and a better standard of living. The critique is instead directed at Modi who mediated himself as the efficient manager of capital in the neoliberal mode of governance. In fact, in pure economic policy terms, there is very little that distinguishes a Congress government from a BJP government. All that Brand Modi did was to promise a faster pace of reforms, and even more reforms rather than a radical change in policy. The public dissatisfaction accrues precisely from the realization that no dramatic change actually took place. What was supposed to be epoch-changing is in fact, more or less, a continuation of what was already there in economic terms. If there is something enduring in this discourse of shifts and transformations, it is the project of "good times" now harnessed to the ever-enchanting dreamworlds of capitalism.

\section{Declaration of Conflicting Interests}

The author declared no potential conflicts of interest with respect to the research, authorship, and/or publication of this article.

\section{Funding}

The author(s) disclosed receipt of the following financial support for the research, authorship, and/or publication of this article: This article is part of a larger research project 'Nation in Motion: Globalisation, Development and Governance in New India', funded by the Danish Agency of Science and Technology.

\section{Note}

1. Swadeshi Jagran Manch was started in 1991 in response to the economic reforms. The invocation of swadeshi ("of one's own country") is a reference to the Indian anticolonial struggle and, here, also means the "self-sufficiency" of the Indian economy.

\section{References}

Bardhan, Pranab. 2010. Awakening Giants, Feet of Clay: Assessing the Rise of India and China. Princeton: Princeton University Press.

Basu, Tapan., Datta, Pradip., Sarkar Sumit., Sarkar, Tanika., and Sen, Sambuddha. 1993. Khakhi Shorts and Saffron Flags. Delhi: Orient Longman.

Bloomberg. 2014. "Hindu Campaigners Backing Modi Risk Spooking India's Allies.” March 20. http://www.bloomberg.com/news/2014-03-19/hindu-campaigners-backing-modi-riskspooking-needed-india-allies.html (accessed September 17, 2014).

Bobbio, Tommaso. 2012. "Making Gujarat Vibrant: Hindutava, Development and the Rise of Subnationalism in India." Third World Quarterly 33 (4): 657-72.

Chakravartty, Paula, and Sreela Sarkar. 2013. "Entrepreneurial Justice: The New Spirit of Capitalism in Emergent India." Popular Communication 11:58-75.

Comaroff, John, and Jean Comaroff. 2009. Ethnicity Inc. Chicago: Chicago University Press. 
Guha, Ram. 2007. India after Gandhi: The History of the World's Largest Democracy. London: Harper.

Jaffrelott, Christophe. 1996. The Hindu Nationalist Movement in India. New York: Columbia University Press.

Jalan, Bimal. 1996. India's Economic Policy: Preparing for the Twenty First Century. Delhi: Penguin.

Kanwal, Rahul. 2013. "RSS Views More Aligned with Modi's? Mohan Bhagwat Says Sangh Not Opposed to FDI, Liberalization." India Today, November 2. http://indiatoday.intoday. in/story/rss-mohan-bhagwat-narendra-modi-fdi-bjp/1/321340.html (accessed September 17, 2014).

Kaur, Ravinder. 2012. "Nation's Two Bodies: Rethinking the Idea of 'New' India and Its Other." Third World Quarterly 33 (4): 603-21.

Kaur, Ravinder. Forthcoming. "Post-exotic India: Remixed Histories and Smart Images in the Contemporary Global."

Khilnani, Sunil. 1997. The Idea of India. Delhi: Penguin.

Koselleck, Reinhart. 2004. Futures past: On the Semantics of Historical Time. New York: Columbia University Press.

Mazzarella, William. 2003. Shoveling Smoke: Advertising and Globalization in Contemporary India. Durham: Duke University Press.

Mukherjee, Gautam. 2014. "Narendra Modi and the Economics of Achche Din." Niti Central, August 6. http://www.niticentral.com/2014/08/06/narendra-modi-and-the-economics-ofachchhe-din-235334.html (accessed September 17, 2014).

North, Michael. 2013. The History of Novelty. Chicago: Chicago University Press.

Roy, Srirupa. 2007. Beyond Belief: India and the Politics of Postcolonial Nationalism. Durham: Duke University Press.

Sen, Amartya, and Jean Dreze. 2013. An Uncertain Glory: India and Its Contradictions. Princeton: Princeton University Press.

Simpson, Edward. 2006. Muslim Society and the Western Indian Ocean: The Seafarers of Kuchch. London: Routledge.

Shani, Ornit. 2007. Communalism, Caste and Hindu Nationalism: The Violence in Gujarat. Cambridge: Cambridge University Press.

Sud, Nikita. 2012. Liberalization, Hindu Nationalism and the State: A Biography of Gujarat. Delhi: Oxford University Press.

\section{Author Biography}

Ravinder Kaur is an Associate Professor of Modern South Asian Studies at the Department of Cross-Cultural and Regional Studies, University of Copenhagen where she also directs the Centre of Global South Asian Studies. She also holds a visiting professorship at Centre of Indian Studies in Africa, Witswatersrand University, Johannesburg. Her current research focuses on India's transformation from a postcolony to "emerging market" in the twenty-first century global political economy. 